International Review of Research in Open and Distributed Learning Volume 19, Number 2

April - 2018

\title{
A Review to Weigh the Pros and Cons of Online, Remote, and Distance Science Laboratory Experiences
}

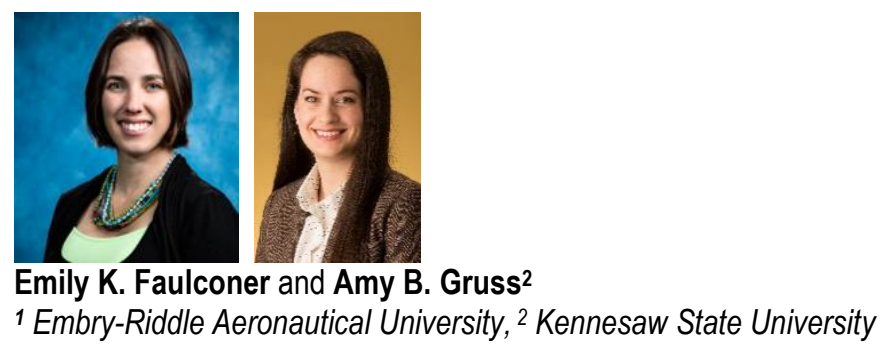

\begin{abstract}
The effectiveness of traditional face to face labs versus non-traditional online, remote, or distance labs is difficult to assess due to the lack of continuity in the literature between terminology, standard evaluation metrics, and the use of a wide variety non-traditional laboratory experience for online courses. This narrative review presents a representative view of the existing literature in order to identify the strengths and weaknesses of non-traditional laboratories and to highlight the areas of opportunity for research.

Non-traditional labs are increasingly utilized in higher education. The research indicates that these nontraditional approaches to a science laboratory experience are as effective at achieving the learning outcomes as traditional labs. While this is an important parameter, this review outlines further important considerations such as operating and maintenance cost, growth potential, and safety. This comparison identifies several weaknesses in the existing literature. While it is clear that traditional labs aid in the development of practical and procedural skills, there is a lack of research exploring if non-traditional laboratory experiments hinder student success in subsequent traditional labs. Additionally, remote lab kits blur the lines between modality by bringing experiences that are more tactile to students outside of the traditional laboratory environment. Though novel work on non-traditional labs continues to be published, investigations are still needed regarding cost differences, acquisition of procedural skills, preparation for advanced work, and instructor contact time between traditional and non-traditional laboratories.
\end{abstract}

Keywords: laboratory, non-traditional laboratory, online, virtual, distance learning, lab format 


\section{Introduction}

Despite a wealth of research on the topic of online versus traditional higher education courses, less focus has been aimed at comparing laboratory experiences. A longstanding question within the science education community is: "What is the effectiveness of lab experiences (traditional vs. non-traditional) relative to each other?" Some studies compared a traditional laboratory course to a non-traditional laboratory course as a whole while others compared the outcomes of an individual lab experiment or activity by modality (Table 1). Some modality comparison studies of science courses that traditionally have a lab neglected to describe if the course analyzed included a laboratory component (Colorado Department of Higher Education, 2012; Rosenzweig, 2012).

Table 1

Non-Comprehensive List of Literature Exploring Non-Traditional Science Laboratory Experiences

\begin{tabular}{|c|c|c|}
\hline Type of comparison & Subject Area & Reference \\
\hline \multirow[t]{9}{*}{ Whole course } & Chemistry & (Casanova \& Civelli, 2006) \\
\hline & Biology & (Biel \& Brame, 2016) \\
\hline & & (Garman, 2012) \\
\hline & & (Hauser, 2013) \\
\hline & & (Johnson, 2002) \\
\hline & & (Riggins, 2014) \\
\hline & Anatomy \& Physiology & $\begin{array}{l}\text { (Barbeau, Johnson, Gibson, \& Rogers, 2013) } \\
\text { (Kuyatt \& Baker, 2014) }\end{array}$ \\
\hline & Soil Science & (Reuter, 2009) \\
\hline & Histology & (Schoenfeld-Tacher, McConnell, \& Graham, 2001) \\
\hline \multirow[t]{4}{*}{$\begin{array}{l}\text { Single lab or subset } \\
\text { of course }\end{array}$} & Chemistry & $\begin{array}{l}\text { (Hawkins \& Phelps, 2013) } \\
\text { (Selmer \& Kraft, 2007) }\end{array}$ \\
\hline & Biology & (Meir, Perry, Stal, Maruca, \& Klopfer, 2005) \\
\hline & Physics & $\begin{array}{l}\text { (Zacharia \& Olympiou, 2011) } \\
\text { (Esquembre, 2015) } \\
\text { (Ko et al., 200o) } \\
\text { (Winer, Chomienne, \& Vazquez-Abad, 200o) }\end{array}$ \\
\hline & $\begin{array}{l}\text { Biochemical } \\
\text { Engineering }\end{array}$ & (Domingues, Rocha, Dourado, Alves, \& Ferreira, 2010) \\
\hline
\end{tabular}

An important consideration before initiating a comparison of lab modalities is to establish the value of the laboratory component in the science course. In introductory science courses designed for non-majors, the laboratory environment may be a tool to reinforce the lecture content (Feig, 2010). However, in many cases, the main goals of the laboratory experience include developing learner skills in making and recording observations as well as deductive reasoning and hypothesis construction (Adlong et al., 2003). Furthermore, the purpose of the lab course often includes the development of practical instrumentation skills and safety awareness or transferable skills such as teamwork, time management, communication, and conflict resolution (Boyer, 2003; Woods, Felder, Rugarcia, \& Stice, 2000). The science lecture courses are not necessarily expected to cultivate these skills and instead tend to deliver general concepts and information. Thus, the laboratory section, both traditional and non-traditional, are often expected to put the ideas into practice and provide students with a practical skills experience (Waldrop, 2013). 
The goal of this review was to organize and synthesize the existing literature in order to outline the benefits and drawbacks of the traditional face-to-face approach for laboratory experiences compared to nontraditional laboratory experiences, which can take many forms. This novel work systematically compared various types of non-traditional lab experiences to evaluate the strengths and weaknesses of the experiences, which no other work currently does in the literature. Furthermore, this investigation identified multiple gaps in the literature and future research in targeted areas was recommended.

\section{Research Method}

An initial survey indicated that the literature was neither robust enough nor was it homogeneous enough to justify a systematic review or meta-analysis. For this reason, a narrative review was executed.

This review focused on literature published between 1997 and 2017. Very little research was performed on distance science laboratory experiences prior to this time frame. Studies included in this review were identified through keyword searches of the ScienceDirect database. Keyword searches included the terms 'remote,' 'virtual,' 'online,' or 'simulation' AND 'laboratory' or 'experiment.' Manual searches of several relevant journals (Journal of College Science Teaching, Journal of Chemical Education, Journal of Research in Science Teaching, American Journal of Distance Education, etc.) were performed. Furthermore, the references lists of key articles in this review were mined. Articles were excluded that did not directly relate to the research question, including articles on laboratory infrastructure and non-teaching laboratories. Studies focused explicitly on engineering or computer laboratory experiments were largely excluded, except when discussing terminology. Conference papers and unpublished materials were not explored. This review is representative, not exhaustive, and some relevant educational studies may have been excluded.

The collected literature was then analyzed based on the following: terminology used, learning outcomes, multiple benefits, practical skill development, cost, growth potential, accessibility, student-instructor communication, safety, and instructional design. These specific topics were investigated because they had the most inconsistencies between articles and/or there was a dearth of information regarding these themes.

\section{Analysis}

\section{Non-Standard Terminology}

Even with a clear research question in mind, the first stumbling block was encountered immediately. Nontraditional labs can include simulated labs, remote labs, lab kits, or some combination. Furthermore, some traditional face-to-face laboratory courses have adopted non-traditional experiences to varying degrees. Confounding this even further is the fact that the literature does not present standard terminology for nontraditional experiences. In order to code the terms used in the literature for various non-traditional laboratory experiences, the following definitions were used. An online laboratory was defined as a laboratory experience where the learner accessed simulated experiments, instruments, or equipment through a computer. A remote laboratory was defined as a laboratory experience where the learner accessed real experiments, instruments, or equipment virtually through a computer. A distance laboratory 
was defined as a laboratory experience where the learner performed hands-on labs outside of a traditional laboratory space through portable laboratory kits, often delivered through the mail.

The inconsistency of the terminology was highlighted by Ma and Nickerson (2006) and no resolution has emerged in the literature since. This lack of standard terminology means that the same online laboratory experience can be labeled "simulated labs," "virtual labs," or "distributed learning labs." Engineering tends to account for a large percentage of the literature on non-traditional labs and these studies often use confusing labeling like referring to remote labs as "online labs" and "remote labs" in the same discussion (Ma \& Nickerson, 2006; Tuttas \& Wagner, 2001). Table 2 provides a sample of variable terms present in the literature.

Table 2

Examples of Terminology for Non-traditional Labs in Literature

\begin{tabular}{lll}
\hline Coding & Term & Reference \\
\hline Online & $\begin{array}{l}\text { Simulated (labs or } \\
\text { experiments) }\end{array}$ & $\begin{array}{l}\text { (Corter, Esche, Chassapis, Ma, \& Nickerson, 2011; Meir et al., } \\
\text { 2005) }\end{array}$ \\
\cline { 2 - 3 } $\begin{array}{l}\text { Virtual (labs or } \\
\text { experiments) }\end{array}$ & $\begin{array}{l}\text { (Dalgarno, Bishop, Adlong, \& Bedgood, 2009; Domingues et } \\
\text { al., 2010; Esquembre, 2015; Ko et al., 2000; Yaron, } \\
\text { Karabinos, Lange, Greeno, \& Leinhardt, 2010) }\end{array}$ \\
\cline { 2 - 3 } & $\begin{array}{l}\text { Virtual learning } \\
\text { environment }\end{array}$ & (Annetta, Klesath, \& Meyer, 2009) \\
\cline { 2 - 3 } & $\begin{array}{l}\text { Internet-based (labs or } \\
\text { experiments) }\end{array}$ & (He, Shen, \& Zhu, 2014) \\
\cline { 2 - 3 } & $\begin{array}{l}\text { Virtual manipulative } \\
\text { experiments }\end{array}$ & (Zacharia \& Olympiou, 2008; Zacharia \& Olympiou, 2011) \\
\cline { 2 - 3 } & $\begin{array}{l}\text { Online (labs or } \\
\text { experiments) }\end{array}$ & (Frt'ala \& Zakova, 2014) \\
\cline { 2 - 3 } & Distributed learning labs & (Winer et al., 2000) \\
\hline Remote & $\begin{array}{l}\text { Remote (labs or } \\
\text { experiments) }\end{array}$ & $\begin{array}{l}\text { Merter et al., 2011; Esquembre, 2015; Herrera, Marquez, } \\
\text { 2004; Meir et al., 2005) }\end{array}$ \\
\cline { 2 - 3 } & Web labs & (Selmer \& Kraft, 2007) \\
\hline Distance & $\begin{array}{l}\text { Take-home (labs or } \\
\text { experiments) }\end{array}$ & Turner \& Parisi, 2008) \\
\cline { 2 - 3 } & At-home experiments & (Casanova \& Civelli, 2006) \\
\cline { 2 - 3 } & Hands-on labs & (Mickle \& Aune, 2008) \\
\hline & $\begin{array}{l}\text { Distance } \\
\text { (learning/education) lab }\end{array}$ & $\begin{array}{l}\text { (Abdel-Salam, Kauffmann, \& Crossman, 2008; Patterson, 2000; } \\
\text { Kimbrough, 2004) }\end{array}$ \\
\hline
\end{tabular}

\section{Comparing Learner Outcomes}

Beyond the lack of standard language to discuss lab modalities, there is no standard evaluation criteria to compare their effectiveness. The literature disagrees on the appropriate measures to use to answer the question of modality equivalence. For example, studies supporting non-traditional labs lean towards outcomes in content knowledge (using quizzes and exams as assessment tools) while studies supporting traditional labs rely on qualitative measures (surveys) (Brinson, 2015). A recent large-scale review of this question concluded that laboratory learning outcomes can be achieved at equal or even greater frequency 
in non-traditional labs than traditional labs, regardless of the outcome category being measured (Brinson, 2015). In a biology-specific review, these findings are supported (Biel \& Brame, 2016).

\section{Comparing Other Variables}

While the effectiveness of a lab experience at achieving the learning outcomes is critical to both educators and administrators, it is not the only variable to consider. There are pedagogical, economic, and safety benefits and drawbacks for all permutations of a laboratory experience. Some variables are straightforward (Table 3) while others fall into a gray zone.

Table 3

Benefits of Traditional and Non-Traditional Laboratory Modalities

\begin{tabular}{lccc}
\hline Benefits & Traditional lab & $\begin{array}{c}\text { Online or } \\
\text { remote }\end{array}$ & $\begin{array}{c}\text { Distance } \\
\text { (lab kit) }\end{array}$ \\
\hline Tangible results with sensory feedback & $\checkmark$ & & $\checkmark$ \\
\hline Low operating \& maintenance costs & & $\checkmark$ & $\checkmark$ \\
\hline Student costs & (variable) & $\checkmark$ & \\
\hline Growth potential \& class sizes & & $\checkmark$ & \\
\hline Replication & $\checkmark$ & $\checkmark$ & $\checkmark$ \\
\hline 24/7 availability & & $\checkmark$ & $\checkmark$ \\
\hline Multiple access opportunities & & $\checkmark$ & $\checkmark$ \\
\hline Extended access time & & $\checkmark$ & (variable) \\
\hline Disability access & $\checkmark$ & $\checkmark$ & \\
\hline Student-instructor contact & $\checkmark$ & (variable) & \\
\hline Safety & & $\checkmark$ & \\
\hline
\end{tabular}

Practical skill development. A common argument in support of traditional laboratory experiences is their role in developing practical skills needed to conduct more advanced research. However, there is no evidence in the literature to suggest that students who took an introductory lab through nontraditional methods perform worse in more advanced labs than those who participated in a traditional introductory lab. With that said, it is fair to say that there are procedural skills that involve sensory feedback where a simulation would simply not be equivalent (Brinson, 2015). A study on the necessity of touch sensory feedback in the K-16 science classrooms (study includes kindergarten through undergraduate level), applying both embodied cognition and additional (touch) sensory channel theories, found that the touch sensory feedback is not necessarily a critical component for learning through science experimentation (Zacharia, 2015). Due to inconsistencies in the literature, Zacharia (2015) was unable to arrive at a framework to describe when touch sensory feedback is ideal for learning through experimentation. Compounding this issue, some laboratories are blurring the lines between modalities. In some cases, robotics bring in a more tactile experience by allowing students to remotely control an experiment and monitor the progress in real-time using video (Rivera, 2014). In other scenarios, laboratory settings involve both physical and virtual manipulatives (Zacharia \& Olympiou, 2008).

Cost. The cost to students in various modalities varies by institution. In some cases, students must pay lab fees and purchase a lab manual for traditional labs while other institutions do not assess lab fees. 
The cost of lab kits vary significantly based on the extent of utilization in the course. Online simulations often have a lower cost than lab kits.

Growth potential. One clear benefit of non-traditional labs is the growth potential. With traditional labs, space is limited by facilities and bottlenecks can occur. Cal-Tech addresses this very issue (Rivera, 2014) by using non-traditional labs. With laboratory kits or online simulations, the limitation of facilities is removed. By offering introductory labs through non-traditional methods, space at the traditional facilities is available for advanced courses. One option for a non-traditional lab is eScience labs, where kits are shipped directly to students globally and the experiments are performed at home, with the assistance of video tutorials, animations, and a lab manual (eScience Labs, 2014). Alternatively, Late Nite Labs (owned by MacMillan) is a company that offers virtual lab environments with over 100 experiment options (Late Nite Labs, 2014).

Accessibility. A clear benefit of non-traditional labs is the expanded accessibility. With online simulations, remote access, and lab kits, learners have the opportunity to engage with the material on their own schedules. This is particularly ideal for non-traditional students who have career and family responsibilities or military deployments. These non-traditional laboratory formats also offer multiple access opportunities that are typically not available in a traditional hands-on laboratory. In many settings using non-traditional labs, the learners have extended time to work with the material, compared to a typical 3 hour weekly lab session. Surveys have indicated that students recognize this as a benefit (Turner \& Parisi, 2008). This format also allows increased access to those with physical or psychological disabilities that prevent them from attending traditional laboratories.

One drawback of the lab kits compared to online or traditional labs is the inability to replicate experiments, particularly if an error was made. The lab kits typically do not provide excess reagents for the microscale experiments. A spill or an oversight in the procedure could prevent the student from being able to complete the experiment. Furthermore, students would not have the opportunity to replicate experiments either for error calculations or to confirm unexpected results. Even in a face-to-face laboratory setting with instructor oversight and guidance, experiments sometimes do not go as planned and students have to start from scratch. This is simply not an option for lab kits.

Another aspect of accessibility is the technological hurdles in getting computer simulations or remote control software to work on the various computers used by students. This poses a unique challenge for students, instructors, and the institutions' IT support staff.

Student-instructor contact time. Another consideration is that non-traditional labs are often asynchronous in nature. This means that the instructor or teaching assistant is not directly in front of the student. This can also limit peer collaboration, depending upon pedagogical choices in the course design. Additionally, the unsupervised nature of asynchronous laboratory experiences can provide a barrier to asking timely questions. For non-traditional labs using lab kits, this can diminish safety awareness and increase risks associated with the laboratory work.

Safety considerations. Another factor to consider is the experiences that each modality can support. Hands-on labs (traditional and lab kits) not only reinforce subject area content but also procedural 
skills. Safety should be an integral component of the course in order to control risks. Due to the unsupervised nature of working with lab kits, the types of experiments are inherently limited. Lab kits need to be able to operate without generating hazardous waste, without advanced instrumentation, and without easily mitigated chemical and physical risks (Boschmann, 2003). The challenge is to not only develop activities that are safe for transportation/delivery and unsupervised experimentation but activities that are also engaging and do not have obvious results that would detract from motivation to complete an experiment. For these reasons, lab kits are microscale and use low-risk chemicals (Gould, 2014).

On the other hand, labs taught through online simulations are strong in reinforcing content but often gloss over safety and often do not approximate actual procedural skills. Remote labs are likely better at approximating procedural skills but safety may not inherently be addressed.

In online labs, there are often safety oversights and over-simplifications. For example, Late Nite Labs does not address hazardous waste. Students dispose of chemical waste in a bin labeled "chemical recycling" with a biohazard symbol. This does not meet waste management standards established by the Resource Conservation and Recovery Act (RCRA; Environmental Protection Agency, 2011). The oversimplification and recognition that it is "not really happening" can affect student motivation (Rivera, 2014). A benefit of online labs, however, is the ability to explore reactions and procedures that are too expensive or simply too dangerous to perform in a hands-on setting. Safety in remote lab experiences is likely to be variable based on the procedure being remotely operated and the presence of personnel at the physical location of the equipment or experiment being remotely operated.

\section{Non-Traditional Lab Course Design Suggestions}

The literature has an abundance of advice regarding creating an effective learning environment in online and non-traditional lecture courses. A common theme, which is easily applicable to the non-traditional laboratory, is active, visible, intentional engagement with students. Deep engagement has been shown to correlate with increases in student performance (Jaggars, Edgecombe, \& Stacey, 2013). Instructional design focused on developing students' skills in self-regulated learning is critical for their success in online courses. Student strengths in time, study environment, and effort regulation have been shown to have a significant positive influence on student performance in online courses while rehearsal, metacognitive self-regulation, time, and study environment correlated with student satisfaction with the course (Puzziferro, 2008). Literature providing course design and execution guidance for online courses is abundant, with less focus placed on providing this guidance specifically for non-traditional labs. Much of the literature on nontraditional labs focuses on infrastructure, student outcomes, or student satisfaction, with little attention to pedagogical design. However, data-supported guidance is present. Inquiry is often considered a best practice for laboratory courses and non-traditional lab courses are no exception. An inquiry cycle presented for online laboratory courses proceeds with Orientation, Conceptualization, Investigation, Conclusion, and Discussion (Zacharia et al., 2015). An analytical taxonomy of guidance for inquiry in online courses presents the following categories: performance dashboard, prompts, process constraints, heuristics, scaffolds, and direct presentation of information (de Jong \& Lazonder, 2014). Zacharia (2015) presents this taxonomy as ideal for consideration in design and execution of non-traditional lab courses, identifying one of the strengths of this taxonomy being that the guidance is classified in a way that is context independent (e.g., inquiry phase or discipline). While at this time the literature does not clearly indicate which types of 
guidance (prompts, process constraints, etc.) are ideal for each inquiry phase, Zacharia (2015) organized existing literature on computer supported inquiry learning according to the taxonomy presented by de Jong and Lazonder (2014).

The literature also reveals additional course features that promote success in an online laboratory environment. As with any online course, student success has been shown to be improved by the use of an online laboratory course orientation (Garman, 2012). The development of an online learning community that allows for peer collaboration has also been demonstrated as a best practice (Garman, 2012; Lowe, Berry, Murray, \& Euan, 2009; Palloff \& Pratt, 2013). Student surveys from online laboratory courses have highlighted the importance of a well-organized calendar for the course that includes hyperlinks to the laboratory activities, assessments, and deliverables (Reeves \& Kimbrough, 2004). For remote laboratory exercises, following industry standards regarding technology platforms ensures students develop skills that are easily transferable and not outdated (Esquembre, 2015).

\section{Conclusion}

In conclusion, a well-designed, non-traditional lab can be as effective as a traditional face-to-face laboratory experience when measuring either content knowledge or student opinions as the metric for equivalence. While there is a limited generalizability of the findings, this mirrors results for meta-analyses comparing traditional and non-traditional modalities for lecture courses and non-science courses (Allen et al., 2004; Means, Toyama, Murphy, Bakia, \& Jones, 2009; Shachar \& Neumann, 2003). However, there are other considerations that institutions must weigh when deciding to take a traditional or non-traditional approach to a laboratory course. The ideal choice of format (traditional, online, remote, or distance) will vary based on the needs and goals of both the institution and the learner.

There are still some rather important questions that have yet to be properly addressed. First, there should be a large-scale cost comparison for various modalities of laboratory courses, for both institutional costs as well as student costs. Second, a long-term study should explore whether non-traditional introductory laboratory experiences properly prepare students for more advanced laboratory experiences, particularly in comparison to those who participated in traditional introductory lab courses. And third, it would be interesting to learn if the instructor-student and peer-to-peer contact time significantly vary in traditional laboratories compared to non-traditional laboratories. With more attention to resolving these questions, the literature may finally arrive on standard terminology and metrics for evaluating equivalency. 


\section{References}

Abdel-Salam, T. M., Kauffmann, P. J., \& Crossman, G. R. (2007). Are distance laboratories effective tools for technology education? American Journal of Distance Education, 21(2), 77-97. doi:10.1080/08923640701299041

Adlong, W., Bedgood, J., D.R., Bishop, A. G., Dillon, K., Haig, T., \& Helliwell, S. (2003). On the path to improving our teaching - reflection on best practices in teaching chemistry. In P. Bright (Ed.), Learning for an unknown future: 2003 Annual international conference of the 26th HERDSA (pp. 1-11). Milperra, Australia: HERDSA.

Allen, M., Mabry, E., Mattrey, M., Bourhis, J., Titsworth, S., \& Burrell, N. (2004). Evaluating the effectiveness of distance learning: A comparison using meta-analysis. Journal of Communication, 54, 402-420. doi:10.1111/j.1460-2466.2004.tbo2636.x

Annetta, L., Klesath, M., \& Meyer, J. (2009). Taking science online: Evaluating presence and immersion through a laboratory experience in a virtual learning environment for entomology students. Journal of College Science Teaching, 37(1), 27-33. Retrieved from http://static.nsta.org/files/jcstogog 27.pdf

Barbeau, M. L., Johnson, M., Gibson, C., \& Rogers, K. A. (2013). The development and assessment of an online microscopic anatomy laboratory course. Anatomical Sciences Education, 6, 246-256. doi:10.1002/ase.1347

Biel, R., \& Brame, C. (2016). Traditional versus online biology courses: Connecting course design and student learning in an online setting. Journal of Microbiology and Biology Education, 17(3), 417422. doi:10.1128/jmbe.v17i3.1157

Boschmann, E. (2003). Teaching chemistry via distance education. Journal of Chemical Education, 8o(6), 704-708. Retrieved from http://pubs.acs.org/doi/pdf/10.1021/edo80p704

Boyer, R. (2003). Concepts and skills in the biochemistry/molecular biology lab. Biochemistry and Molecular Biology Education, 31(2), 102-105. doi:10.1002/bmb.2003.494031020192

Brinson, J. (2015). Learning outcome achievement in non-traditional (virtual and remote) versus traditional (hands-on) laboratories: A review of the empirical research. Computers \& Education, 87, 218-237. doi:10.1016/j.compedu.2015.07.003

Casanova, R. S., \& Civelli, J. L. (2006). Distance learning: A viable alternative to the conventional lecturelab format in general chemistry. Journal of Chemical Education, 83(3), 501. doi:10.1021/edo83p501

Colorado Department of Higher Education. (2012). Online versus traditional learning: A comparison study of Colorado community college science classes. Colorado Department of Higher Education. Retrieved from 
http://wcet.wiche.edu/sites/default/files/1622CCCSOnlinevsTraditionalScienceStudyReportJune 2012update.pdf

Corter, J. E., Esche, S. K., Chassapis, C., Ma, J., \& Nickerson, J. V. (2011). Process and learning outcomes from remotely-operated, simulated, and hands-on student laboratories. Computers \& Education, 57(3), 2054-2067. doi:10.1016/j.compedu.2011.04.009

Dalgarno, B., Bishop, A. G., Adlong, W., \& Bedgood, J., D.R. (2009). Effectiveness of a virtual laboratory as a preparatory resource for distance education chemistry students. Computers \& Education, 53(3), 853-865. doi:10.1016/j.compedu.2009.05.005

de Jong, T., \& Lazonder, A. W. (2014). The guided discovery principle in multimedia learning. In E. Mayer (Ed.), The cambridge handbook of multimedia learning (2nd ed., pp. 371-390). Cambridge: Cambridge University Press.

Domingues, L., Rocha, I., Dourado, F., Alves, M., \& Ferreira, E. C. (2010). Virtual laboratories in (bio)chemical engineering education. Education for Chemical Engineers, 5(2), e22-e27. doi:10.1016/j.ece.2010.02.001

Environmental Protection Agency. (2011). Hazardous waste rules. Resource Conservation and Recovery Act, 40 CFR 260.

eScience Labs. (2014). Retrieved from http://esciencelabs.com/

Esquembre, F. (2015). Facilitating the creation of virtual and remote laboratories for science and engineering education. IFAC-PapersOnLine, 48(29), 49-58. doi:10.1016/j.ifacol.2015.11.212

Feig, A. D. (2010). An online introductory physical geology laboratory: From concept to outcome. Geosphere, 6(6), 942-951. doi:10.1130/GESo0511.1

Frt'ala, T., \& Zakova, K. (2014). Virtualization - an answer to secure development of online experiments. IFAC Proceedings Volumes, 47(3), 9738-9743. doi:10.3182/20140824-6-ZA-1003.02454

Garman, D. E. (2012). Student success in face-to-face and online sections of biology courses at a community college in east Tennessee (Doctoral dissertation). Retrieved from http://dc.etsu.edu/etd/1408/

Gould, J. (2014). Online education: The rise of virtual labs. Retrieved from http://blogs.nature.com/naturejobs/2014/o9/22/online-education-the-rise-of-virtual-labs/

Hauser, L. K. (2013). An examination of the predictive relationship between mode of instruction and student success in introductory biology (Doctoral dissertation). Retrieved from https://commons.vccs.edu/cgi/viewcontent.cgi?article=1070\&context=inquiry 
Hawkins, I., \& Phelps, A. (2013). Virtual laboratory vs. traditional laboratory: Which is more effective for teaching electrochemistry. Chemistry Education Research and Practice, 14(4), 516-523. doi:10.1039/C3RPooo7oB

He, Z., Shen, Z., \& Zhu, S. (2014). Design and implementation of an internet-based electrical engineering laboratory. ISA Transactions, 53(5), 1377-1382. doi:10.1016/j.isatra.2013.12.035

Herrera, R. S., Marquez, M. A., Mejias, A., Tirado, R., \& Andujar, J. M. (2015). Exploring the usability of a remote laboratory for photovoltaic systems. IFAC-PapersOnLine, 48(29), 7-12. doi:10.1016/j.ifacol.2015.11.205

Jackson, M. D. (1998). A distance-education chemistry course for nonmajors. Journal of Science Education and Technology, 7(2), 163-170. doi:10.1023/A:1022516624477

Jaggars, S. S., Edgecombe, N., \& Stacey, G. W. (2013). Creating an effective online instructor presence. Columbia University: Community College Research Center. Retrieved from https://eric.ed.gov/?id=ED542146

Johnson, M. (2002). Introductory biology online: Assessing outcomes of two student populations. Journal of College Science Teaching, 31(5), 312-317. Retrieved from http://www.jstor.org/stable/42992241

Kennepohl, D., Baran, J., \& Currie, R. (2004). Remote instrumentation for the teaching laboratory. Journal of Chemical Education, 81(12), 1814. doi:10.1021/edo81p1814

Ko, C. C., Chen, B. M., Chen, S. H., Ramakrishnan, V., Chen, R., Hu, S. Y., \& Zhuang, Y. (2000). A largescale web-based virtual oscilloscope laboratory experiment. Engineering Science and Education Journal, 9(2), 69-76. doi:10.1049/esej:20000204

Kuyatt, B. L., \& Baker, J. D. (2014). Human anatomy software use in traditional and online anatomy laboratory classes: Student-perceived learning benefits. Journal of College Science Teaching, 43(5), 14-19. Retrieved from http://static.nsta.org/files/jcst1405_14.pdf

Late Nite Labs. (2014). Retrieved from http://latenitelabs.com/

Lowe, D., Berry, C., Murray, S., \& Euan, L. (2009). Adapting a remote laboratory architecture to support collaboration and supervision. International Journal of Online Engineering, 5(S1), 51-56. doi:10.3991/ijoe.v5s1.932

Ma, J., \& Nickerson, J. V. (2006). Hands-on, simulated, and remote laboratories: A comparative literature review. ACM Computing Surveys, 38, 1-24. Retrieved from https://web.stevens.edu/jnickerson/ACMComputingSurveys2006MaNickerson.pdf

Means, B., Toyama, Y., Murphy, R., Bakia, M., \& Jones, K. (2009). Evaluation of evidence-based practices in online learning: A meta-analysis and review of online learning studies. 
Washington, D.C.: U.S. Department of Education. Retrieved from https://eric.ed.gov/?id=ED505824

Meir, E., Perry, J., Stal, D., Maruca, S., \& Klopfer, E. (2005). How effective are simulated molecular-level experiments for teaching diffusion and osmosis? Cell Biology Education, 4(3), 235-248. doi:10.1187/cbe.04-09-0049

Mickle, J. E., \& Aune, P. M. (2008). Development of a laboratory course in nonmajors general biology for distance education. Journal of College Science Teaching, 37(5), 35-39. Retrieved from http://static.nsta.org/files/jcsto805 3.p.pdf

Palloff, R. M., \& Pratt, K. (2013). Lessons from the virtual classroom: The realities of online teaching (2nd ed.) San Francisco, CA: John Wiley \& Sons.

Patterson, M. J. (2000). Developing and internet-based chemistry class. Journal of Chemical Education, 77(5), 554. doi:10.1021/edo77p554

Puzziferro, M. (2008). Online technologies self-efficacy and self-regulated learning as predictors of final grade and satisfaction in college-level online courses. American Journal of Distance Education, 22(2), 72-89. doi:10.1080/08923640802039024

Reeves, J., \& Kimbrough, D. (2004). Solving the laboratory dilemma in distance learning general chemistry. Journal of Asynchronous Learning Networks, 8(3), 47-51. Retrieved from file:///C:/Users/Owner/Downloads/v8n3_reeves_1.pdf

Reuter, R. (2009). Online versus in the classroom: Student success in a hands-on lab class. American Journal of Distance Education, 23, 151-162. doi:10.1080/08923640903080620

Riggins, M. E. (2014). Online versus face-to-face biology: A comparison of student transactional distance, approach to learning, and knowledge outcomes (Doctoral dissertation). Retrieved from https://aquila.usm.edu/dissertations/19/

Rivera, C. (2014, November 15). For some students, virtual labs replace hands-on science experiments. Los Angeles Times. Retrieved from http://www.latimes.com/local/education/la-me-college-labs20141115-story.html

Rosenzweig, A. H. (2012). Comparing biology grades based on instructional delivery and instructor at a community college: Face-to-face course versus online course (Doctoral dissertation). Retrieved from scholarworks.uno.edu/cgi/viewcontent.cgi?article=2564\&context=td

Schoenfeld-Tacher, R., McConnell, S., \& Graham, M. (2001). Do no harm: A comparison of the effects of on-line vs. traditional delivery media on a science course. Journal of Science Education and Technology, 1O, 257-265. doi:10.1023/A:1016690600795 
Selmer, A., \& Kraft, M. (2007). Weblabs in chemical engineering education. Education for Chemical Engineers, 2(1), 38-45. doi:10.1205/eceo6o18

Shachar, M., \& Neumann, Y. (2003). Differences between traditional and distance education academic performances: A meta-analytic approach. The International Review of Research in Open and Distributed Learning, 4(2) Retrieved from http://www.irrodl.org/index.php/irrodl/\%20article/viewArticle/153/234

Turner, J., \& Parisi, A. (2008). A take-home physics experiment kit for on-campus and off-campus students. Journal of Teaching Science, 54(2), 1-2. Retrieved from https://core.ac.uk/download/pdf/11037754.pdf

Tuttas, J., \& Wagner, B. (2001). Distributed online laboratories. Paper presented at the International Conference on Engineering Education, Oslo, Norway. Retrieved from ftp://labattmot.ele.ita.br/ele/lfilipe/Lab Real Remoto/Artigos/Lab Remoto/Tuttas J Distrib uited Online Labs.pdf

Waldrop, M. M. (2013). Education online: The virtual lab. Nature, 499(7458), 268. Retrieved from http://www.nature.com/news/education-online-the-virtual-lab-1.13383

Winer, L. R., Chomienne, M., \& Vazquez-Abad, J. (2000). A distributed collaborative science learning laboratory on the internet. American Journal of Distance Education, 14(1), 47-62. doi:10.1080/08923640009527044

Woods, D. R., Felder, R. M., Rugarcia, A., \& Stice, J. (2000). The future of engineering education III. developing critical skills. Chemical Engineering Education, 34(2), 108-117. Retrieved from https://www.researchgate.net/profile/Richard Felder/publication/2625823 The future of en gineering education III Developing critical skills/links/54b7e5coocf28faced6oc57a/Thefuture-of-engineering-education-III-Developing-critical-skills.pdf

Yaron, D., Karabinos, M., Lange, D., Greeno, J. G., \& Leinhardt, G. (2010). The ChemCollective - virtual labs for introductory chemistry courses. Science, 328(5978), 584-585. doi:10.1126/science.1182435

Zacharia, Z. (2015). Examining whether touch sensory feedback is necessary for science learning through experimentation: A literature review of two different lines of research across K-16. Educational Research Review, 16, 116-137. doi:10.1016/j.edurev.2015.10.001

Zacharia, Z., Manoli, C., Xenofontos, N., de Jong, T., Pedaste, M., van Riesen, A. A. N. . . Tsourlidaki, E. (2015). Identifying potential types of guidance for supporting student inquiry when using virtual and remote labs in science: A literature review. Educational Technology Research and Development, 63(2), 257-302. doi:10.1007/s11423-015-9370-0 
Zacharia, Z., \& Olympiou, G. (2008). Effects of experimenting with physical and virtual manipulatives on students' conceptual understanding in heat and temperature. Journal of Research in Science Teaching, 45(9), 1021-1035. doi:10.1002/tea.20260

Zacharia, Z., \& Olympiou, G. (2011). Physical versus virtual manipulative experimentation in physics learning. Learning and Instruction, 21(3), 317-331. doi:10.1016/j.learninstruc.2010.03.001

\section{Athabasca} University

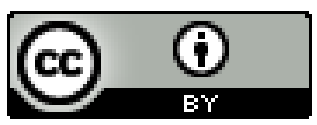

